\title{
Herbicide management in glyphosate and sulfonylurea-tolerant soybeans
}

\section{Manejo de herbicidas em soja tolerante a glifosato e sulfonilureias}

\author{
André Felipe Moreira Silva1* (10) (orcid.org/0000-0002-4846-8089) \\ Alfredo Junior Paiola Albrecht ${ }^{2}$ (1) (orcid.org/0000-0002-8390-3381) \\ Eduardo Seity Furlan Kashivaqui ${ }^{2}$ (1) (orcid.org/0000-0002-0759-5161) \\ Gustavo Soares da Silva' (1) (orcid.org/0000-0003-3267-7254) \\ Ana Ligia Giraldeli ${ }^{1}$ (i) (orcid.org/0000-0002-7452-0370) \\ Lucas da Silva Araújo' 1 (1) (orcid.org/0000-0003-3958-6881) \\ Leandro Paiola Albrecht ${ }^{2}$ (1) (orcid.org/0000-0003-3512-6597) \\ Giovani Apolari Ghirardello' (10) (orcid.org/0000-0001-6381-2581) \\ Ricardo Victoria Filho' ${ }^{1}$ (1) (orcid.org/0000-0002-2185-8773)
}

\begin{abstract}
There is little information on the efficacy and selectivity of sulfonylureas, isolated and in association with glyphosate, in glyphosate and sulfonylurea-tolerant soybeans. Thus, the present study aims to evaluate the efficacy of weed control and selectivity of sulfonylureas, isolated and in association with glyphosate, at post-emergence (V4) of RR2/STS soybean. The experiments were conducted in the in areas located in Piracicaba City, São Paulo State (SP), Brazil (experiment I) and Palotina City, Paraná State (PR), Brazil (experiment II). Treatments were composed of application of the herbicides sulfometuron, chlorimuron, halosulfuron, ethoxysulfuron and glyphosate, isolated and in association, in the BMX Garra RR2/ STS cultivar. Experiment I was conducted focusing on the evaluation of the efficacy of weed control; whereas experiment II focused mainly on the evaluation of herbicide selectivity. The experimental design was the randomized complete block, with four replications. Crop injury, weed control, and variables related to agronomic performance were evaluated. Data were submitted to analysis of variance, and the means of the treatments were compared with the Tukey test. Sulfonylureas in association with glyphosate were effective in weed control and selective for the BMX Garra RR2/STS soybean cultivar. The sulfometuron + chlorimuron + glyphosate association presented phytotoxic potential for the BMX Garra RR2/STS cultivar.
\end{abstract}

KEYWORDS: Glycine $\max$; STS; weed control; herbicides selectivity; agronomic performance.
RESUMO: Há poucas informaçóes sobre a eficácia e seletividade de sulfonilureias, isoladas e associadas ao glifosato, na soja tolerante ao glifosato e às sulfonilureias. Assim, o presente estudo teve como objetivo avaliar a eficácia no controle de plantas daninhas e seletividade de sulfonilureias, isoladas e em associação com o glifosato, em pós-emergência (V4) de soja RR2/STS. Os experimentos foram conduzidos em áreas localizadas nos municípios de Piracicaba, São Paulo (SP), Brasil (experimento I) e Palotina, Paraná (PR), Brasil (experimento II). Os tratamentos foram compostos pela aplicação dos herbicidas sulfometurom, clorimurom, halossulfurom, etoxissulfurom e glifosato, isolados e em associação, no cultivar BMX Garra RR2/STS. O experimento I foi realizado com o foco principal na avaliação da eficácia no controle de plantas daninhas; ao passo que o experimento II se concentrou principalmente na avaliação da seletividade dos herbicidas. O delineamento experimental foi o de blocos casualizados, com quatro repetiçóes. Foram avaliados sintomas de injúria, controle de plantas daninhas e variáveis relacionadas ao desempenho agronômico. Os dados foram submetidos à análise de variância, e as médias dos tratamentos foram comparadas pelo teste de Tukey. Sulfonilureias associadas ao glifosato foram eficazes no controle de plantas daninhas e seletivas para o cultivar de soja BMX Garra RR2/STS. A associação sulfometurom + clorimurom + glifosato apresentou potencial fitotóxico para o cultivar BMX Garra RR2/STS.

PALAVRAS-CHAVE: Glycine max; STS; controle de plantas daninhas; seletividade de herbicidas; desempenho agronômico.

\footnotetext{
'Universidade de São Paulo, Escola Superior de Agricultura “Luiz de Queiroz" - Piracicaba (SP), Brazil

2Universidade Federal do Paraná - Palotina (PR), Brazil

*Corresponding author: afmoreirasilva@hotmail.com

Received on: 05/16/2019. Accepted on: 06/21/2020
} 


\section{INTRODUCTION}

Glyphosate tolerant transgenic soybean (Roundup Ready ${ }^{\circledR}$ soybean - $\mathrm{RR}^{\circledR}$ soybean) was developed by introducing a gene called cp4epsps from the bacteria Agrobacterium tumefaciens, strain CP4. This gene encodes an EPSPs enzyme insensitive to glyphosate, thus making soybean plants tolerant to this herbicide (PADGETTE et al., 1995). The "second generation" of glyphosate-tolerant soybean (RR2 soybean) was developed with a different technique of insertion of the cptepsps gene (in addition to the cry $1 A c$ gene, from the bacterium Bacillus thuringiensis $(\mathrm{Bt})$, which makes insects resistant), under the trademark Intacta ${ }^{\circledast}$ Roundup Ready ${ }^{\oplus}$ Pro (BERNARDI et al., 2012).

On the other hand, sulfonylurea tolerant soybean $\left(\mathrm{STS}^{\oplus}\right)$ is not a transgenic crop, which has been developed with the technique of seed mutagenesis using ethyl methanesulfonate (EMS) alkylating agent, which does not cause mutation by insertion into the DNA, but by the modification of the base already present (ROGOZIN et al., 2001). Mutant seeds from the 'Williams 82 ' soybean cultivar were selected according to tolerance to chlorsulfuron sulfonylurea. Thus, soybean cultivar W20 STS was developed, which presented high tolerance in post- and pre-emergence for some sulfonylureas (SEBASTIAN et al., 1989). Such tolerance is conferred by semidominant alleles called $A l s 1$ and $A l s 2$ (WALTER et al., 2014; MANTOVANI et al., 2017).

STS cultivars are highly tolerant to the chlorimuron herbicide, which can be applied up to four times above the recommended dose for non-STS cultivars (GREEN, 2007; ROSO; VIDAL, 2011; ALBRECHT et al., 2017). They also show tolerance to other herbicides of the sulfonylureas group.

STS cultivars were commercially launched first in the United States, in 1994 (GREEN, 2012). In Brazil, the first cultivars were only introduced in 2011. Currently, there are commercially available cultivars that mutually present RR or RR2 and STS technologies, allowing the association between sulfonylurea and glyphosate in weed management.

Glyphosate is an herbicide that inhibits the EPSPs enzyme, has a broad action spectrum in weed control and is selective only for transgenic tolerant crops. Sulfonylureas inhibit the ALS enzyme and have action mainly on eudicotyledonous weeds, but some molecules also present action on Cyperaceae (OLIVEIRA JÚNIOR, 2011).

However, there is little information on the efficacy and selectivity of sulfonylureas, such as halosulfuron, ethoxysulfuron, sulfometuron, among others, isolated and in association with glyphosate in soybean. These associations are believed to be effective in weed control and selective for RR2/STS soybean plants. Thus, the present study aimed to evaluate the efficacy of weed control and selectivity of sulfonylureas, isolated and in association with glyphosate, for post-emergence (V4) application of RR2/STS soybean.

\section{MATERIALS AND METHODS}

\section{Field experiments}

The experiments were conducted in the 2017/18 season, in areas located in Piracicaba City, São Paulo State, Brazil, (experiment I), and Palotina City, Paraná State, Brazil (experiment II). The BMX Garra RR2/STS cultivar was used, which presents indeterminate growth habit and 6.3 relative maturity group.

According to the classification of Köppen, the Piracicaba's climate is characterized as Cwa - humid subtropical, with drought during winter. Palotina's climate is, on the other hand, $\mathrm{Cfa}$ - mesothermic, humid subtropical, with predominance of hot summers, low frequency of severe frost and a tendency of concentration of rains during summer. The distribution of precipitation and temperature along the conduction period of each experiment is shown below (Fig. 1).

The fertilization was carried out to correct the soil, considering the extraction of the crop. Sowing of the experiments was performed in the second fortnight of October 2017. The physical and chemical analysis of the soil of experimental areas is presented below (Table 1).

The treatments were composed by the application of herbicides, described in Table 2. The experimental design was the randomized complete block, with four replications. The experimental units were made up of $5 \mathrm{~m}$ long plots and five soybean rows, spaced at $0.45 \mathrm{~m}$, the three central lines being considered as useful area, discarding the first and last meter of the plot.

Treatments were applied via $\mathrm{CO}_{2}$ pressurized coastal sprayer, with bar equipped with four spray nozzle (XR 110.02) at a constant pressure of $2 \mathrm{bar}$, a flow rate of $0.65 \mathrm{~L} \mathrm{min.}^{-1}$, working at a height of $50 \mathrm{~cm}$ from the target and at a speed of $1 \mathrm{~m} \mathrm{~s}^{-1}$, reaching an applied band of $50 \mathrm{~cm}$ wide with spray nozzle, and providing a spray volume of $200 \mathrm{~L} \mathrm{ha}^{-1}$.

Experiment I was conducted focusing on the evaluation of the efficacy of weed control; whereas experiment II focused mainly on the evaluation of herbicide selectivity. Thus, in experiment II, all the plots were kept free from the presence of weeds, with manual weeding. The area of experiment I was infested, with emphasis on the weeds Alternanthera tenella, Commelina benghalensis, Richardia brasilensis, Ageratum conyzoides, Eleusine indica and Digitaria sp.

\section{Data collection}

Crop injury was evaluated in both experiments; this evaluation was performed 7, 14, 21, and 28 days after application (DAA). In experiment $\mathrm{I}$, in the same evaluation dates, weed control was evaluated. For the evaluation of crop injury and weed control, percentage visual marks were assigned, varying from 0 to $100 \%$ in each experimental unit, in which 0 represents no injuries and $100 \%$, the death of plants (VELINI et al., 1995). 
For experiment I, at $28 \mathrm{DAA}$, weed was collected from an area with $0.25 \mathrm{~m}^{2}$ in each plot. The collected material was dried in a forced ventilation oven at $65^{\circ} \mathrm{C}$ for 72 hours, after which the dry mass of weeds was measured in an analytical balance with accuracy of two decimal places.

\section{A Season 2017/18, Piracicaba - SP}

01/10/2017 - 27/02/2018

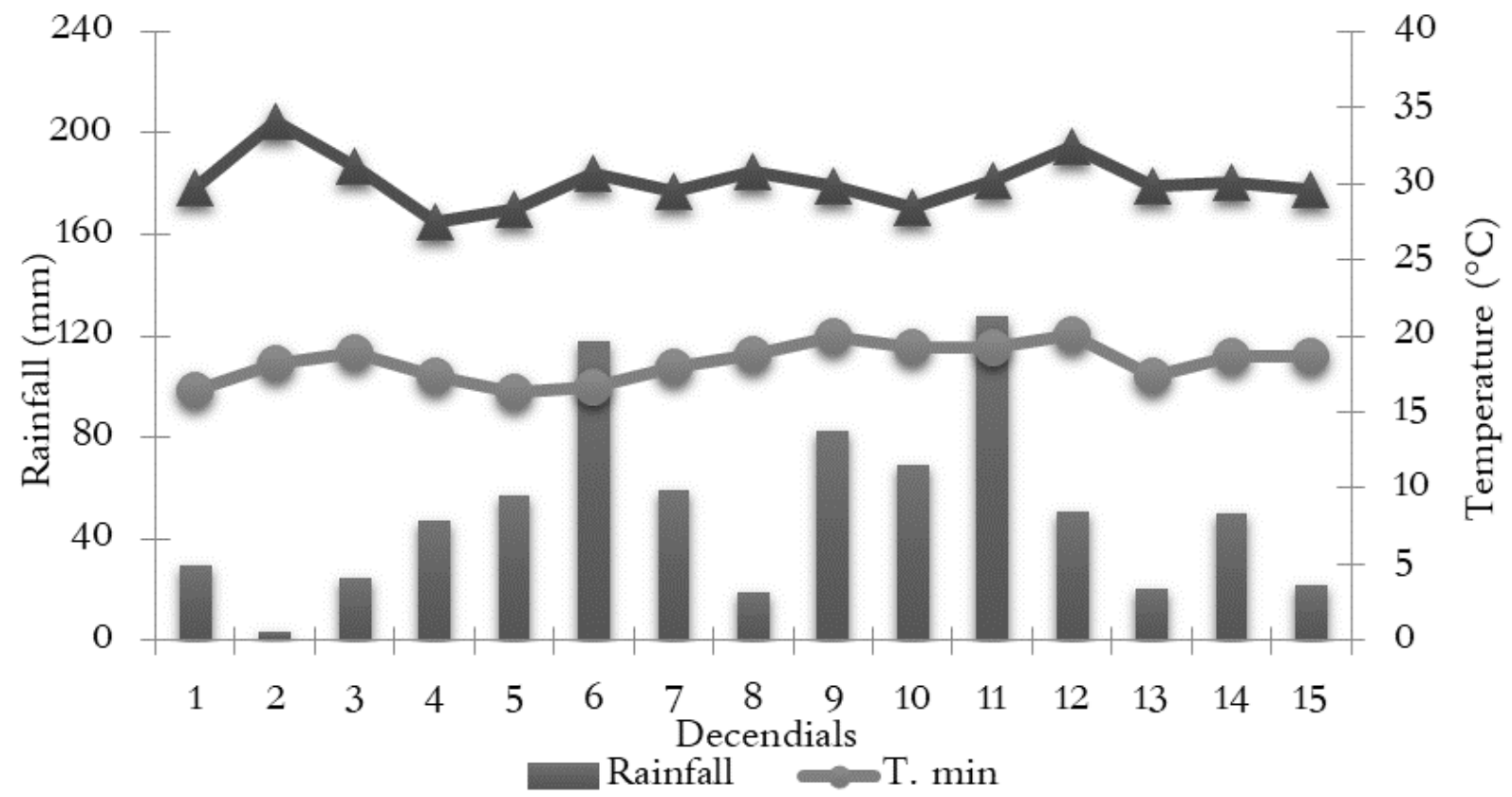

B Season 2017/18, Palotina - PR

$01 / 10 / 2017-27 / 02 / 2018$

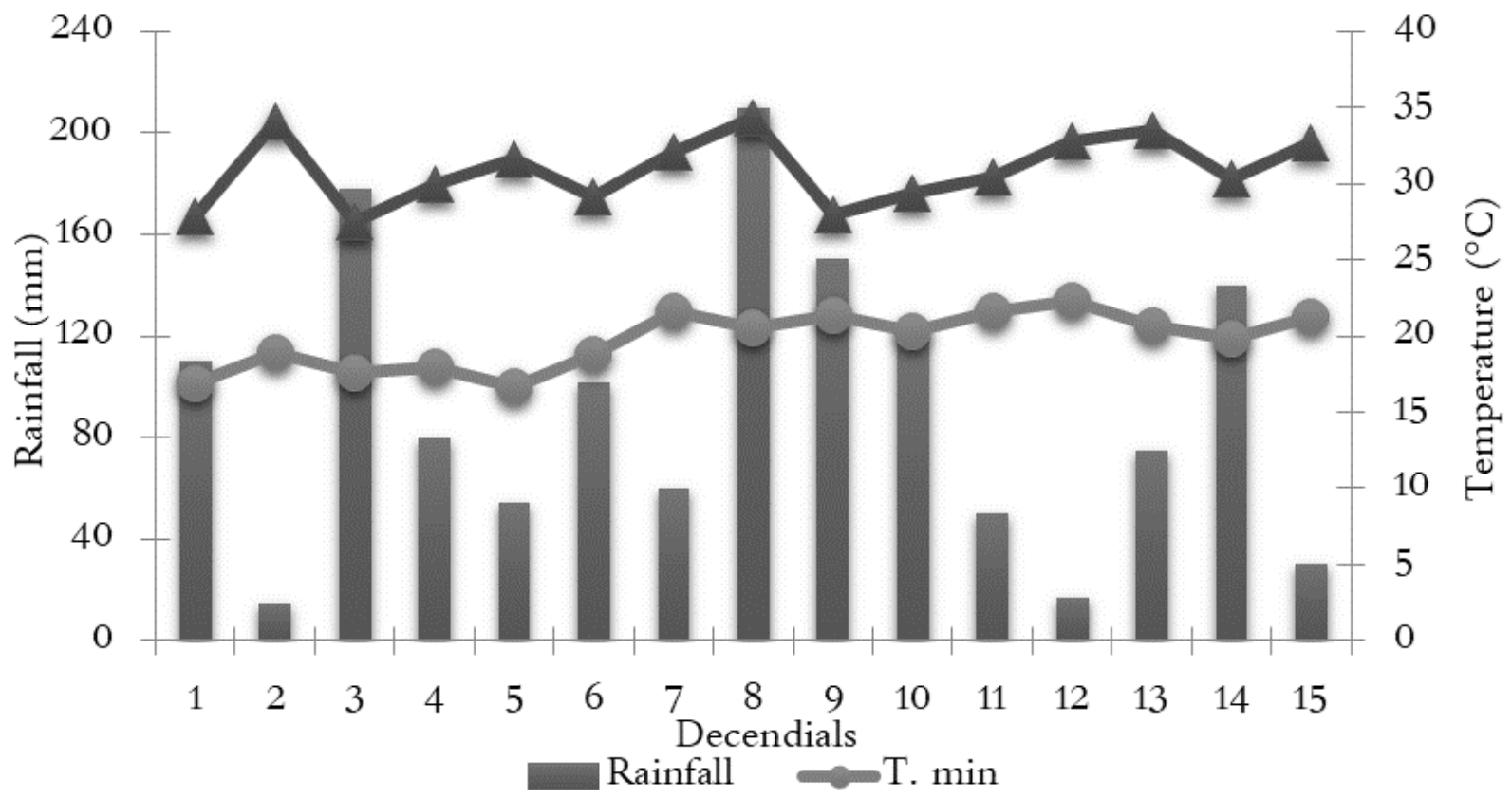

Source: LEB - USP/ESALQ (A), C.Vale - Cooperativa Agroindustrial (B).

Figure 1. Representation of rainfall $(\mathrm{mm})$, maximum $\left({ }^{\circ} \mathrm{C}\right)$ and minimum $\left({ }^{\circ} \mathrm{C}\right)$ temperatures during the season of experiments $\mathrm{I}$ (A) and II (B). 
Evaluation of variables related to agronomic performance (plant height, height of first pod insertion, and yield) was performed. For experiment I, only yield evaluation was performed. Height evaluations were carried out when the plants reached the R7 stage; to determine the two variables, 10 plants were evaluated, randomly chosen in the useful area of the plots, and the measurements were carried out using a wooden millimeter ruler. The results are expressed in centimeters.

To evaluate the yield, plants were taken from the two central lines, discarding the first and last meter of the plot, totaling a harvested area of $2.7 \mathrm{~m}^{2}$. The plants were at the $\mathrm{R} 8$ stage, i.e., $95 \%$ of the pods had the typical mature pod color (FEHR et al., 1971). Afterwards, the pods were threshed in a threshing machine for experiments and cleaned with the aid of sieves. The grains produced in each plot had their mass measured and the moisture corrected to $13 \%$. From these data, the yield was calculated.

\section{Statistical analyses}

Data were submitted to analysis of variance and the means of the treatments were compared with the TUKEY (1949) test, at $\mathrm{p}<0.05$ (PIMENTEL-GOMES; GARCIA, 2002).

\section{RESULTS}

\section{Selectivity of herbicides}

Higher crop injury was verified for herbicide associations, especially for sulfometuron association $\left(15 \mathrm{~g}\right.$ a.i. $\left.\mathrm{ha}^{-1}\right)+$ chlorimuron $\left(20 \mathrm{~g}\right.$ a.i. ha $\left.\mathrm{h}^{-1}\right)+$ glyphosate $\left(960 \mathrm{~g}\right.$ a.e. ha $\left.{ }^{-1}\right)$. This association resulted in $8.75 \%$ injury at 7 DAA for experiment I (Table 3), and $38.50 \%$ at 14 DAA for experiment II (Table 4 ).

For experiment I, there was a reduction in the percentages of injury throughout the evaluations. As already noted, triple association caused greater injury in soybean plants at
7 DAA. The association halosulfuron $\left(80 \mathrm{~g}\right.$ a.i. ha $\left.{ }^{-1}\right)+$ glyphosate also caused injury in soybean plants $(5 \%)$, differing from the control (no application); other treatments did not differ from the control one. In the following evaluations, only the triple association caused injuries in the soybean plants, differing from the control one. At 28 DAA, the triple association provided soybean plants with a crop injury of $2.75 \%$, being a low value. Other treatments did not provide any symptoms of injury to RR2/STS soybean plants in this evaluation.

For experiment II, besides the triple association, other herbicidal treatments caused injuries to soybean plants. Especially the associations of sulfonylureas with glyphosate. At 7 DAA, only the chlorimuron and glyphosate herbicides, applied in isolation, did not differ from the control. At 14 DAA,

Table 2. Treatments applied in post-emergence RR2/STS soybeans. Season $2017 / 18$.

\begin{tabular}{|lcc|}
\hline \multicolumn{2}{|c|}{ Treatments $^{1}$} & Rates $^{2}$ \\
\hline 1 & control (without weeding) & - \\
\hline 2 & control (with weeding) & - \\
\hline 3 & sulfometuron & 15 \\
\hline 4 & chlorimuron & 20 \\
\hline 5 & sulfometuron + chlorimuron & $15+20$ \\
\hline 6 & ethoxysulfuron & 60 \\
\hline 7 & halosulfuron & 80 \\
\hline 8 & glyphosate & 960 \\
\hline 9 & sulfometuron + glyphosate & $15+960$ \\
\hline 10 & chlorimuron + glyphosate & $20+960$ \\
\hline 11 & sulfometuron + chlorimuron + & $15+20+960$ \\
\hline 12 & glyphosate & $60+960$ \\
\hline 13 & ethoxysulfuron + glyphosate & $80+960$ \\
\hline
\end{tabular}

${ }^{1}$ Comercial products: Curavial ${ }^{\circledast}$ (sulfometuron), Classic $^{\circledast}$ (chlorimuron), Gladium ${ }^{\circledast}$ (ethoxysulfuron), Sempra ${ }^{\circledR}$ (halosulfuron), Roundup ${ }^{\circledR}$ Original (glyphosate).

${ }^{2}$ Rates in grams of active ingredient per hectare ( $\mathrm{g}$ a.i. ha $\left.{ }^{-1}\right)$, for glyphosate rates in grams of acid equivalent per hectare ( $\mathrm{g}$ a.e. $\mathrm{ha}^{-1}$ ).

Table 1. Result of chemical and physical soil analysis of the experimental area, in depth from 0 to $20 \mathrm{~cm}$.

\begin{tabular}{|c|c|c|c|c|c|c|c|c|c|}
\hline \multicolumn{10}{|c|}{ Piracicaba City - São Paulo } \\
\hline $\mathrm{pH}\left(\mathrm{CaCl}_{2}\right)$ & Al & $\mathrm{H}+\mathrm{Al}$ & $P($ resin $)$ & $\mathrm{K}$ & $\mathrm{Ca}$ & $\mathrm{Mg}$ & SB & CEC & V \\
\hline 5.3 & $<1.0$ & 25.0 & 10.0 & 2.8 & 26.0 & 13.0 & 41.8 & 66.8 & 63.0 \\
\hline Clay & & & \multicolumn{3}{|c|}{ Silt } & \multicolumn{4}{|c|}{ Sand } \\
\hline 41.0 & & & \multicolumn{3}{|c|}{5.0} & \multicolumn{4}{|c|}{54.0} \\
\hline \multicolumn{10}{|c|}{ Palotina - Paraná } \\
\hline $\mathrm{pH}\left(\mathrm{CaCl}_{2}\right)$ & $\mathrm{Al}$ & $H+A l$ & P (Mehlich) & K & $\mathrm{Ca}$ & $\mathrm{Mg}$ & SB & CEC & V \\
\hline 5.6 & $<1.0$ & 46.1 & 19.4 & 2.2 & 55.1 & 14.7 & 72.0 & 118.1 & 61.0 \\
\hline Clay & & & \multicolumn{3}{|c|}{ Silt } & \multicolumn{4}{|c|}{ Sand } \\
\hline 66.3 & & & \multicolumn{3}{|c|}{18.7} & \multicolumn{4}{|c|}{15.0} \\
\hline
\end{tabular}

Units: Al, $\mathrm{H}+\mathrm{Al}, \mathrm{K}, \mathrm{Ca}, \mathrm{Mg}$, sum of bases (SB), and cation exchange capacity (CTC) ( $\left.\mathrm{mmol}_{\mathrm{c}} \mathrm{dm}^{-3}\right) ; \mathrm{P}\left(\mathrm{mg} \mathrm{dm}^{-3}\right)$; base saturation (V), clay, silt, and sand (\%). 
Table 3. Crop injury (\%) at 7, 14, 21 , and 28 days after application of RR2/STS soybeans under application of post-emergence herbicides. Piracicaba City, São Paulo (experiment I), season 2017/18.

\begin{tabular}{|c|c|c|c|c|c|c|c|c|c|}
\hline \multirow{2}{*}{\multicolumn{2}{|c|}{ Treatments ${ }^{1}$}} & \multicolumn{8}{|c|}{ Crop injury } \\
\hline & & \multicolumn{2}{|c|}{7} & \multicolumn{2}{|c|}{14} & \multicolumn{2}{|c|}{21} & \multicolumn{2}{|c|}{28} \\
\hline 1 & co (without weeding) & 0.00 & a & 0.00 & a & 0.00 & a & 0.00 & a \\
\hline 2 & co (with weeding) & 0.00 & a & 0.00 & a & 0.00 & $\mathrm{a}$ & 0.00 & a \\
\hline 3 & sul & 1.00 & $a b$ & 0.50 & $\mathrm{a}$ & 0.00 & a & 0.00 & a \\
\hline 4 & chl & 0.00 & $\mathrm{a}$ & 0.00 & $a$ & 0.00 & $a$ & 0.00 & a \\
\hline 5 & $\mathrm{sul}+\mathrm{chl}$ & 1.75 & $a b$ & 0.75 & $a$ & 0.75 & $a b$ & 0.00 & a \\
\hline 6 & eth & 0.25 & $a$ & 0.25 & $a$ & 0.00 & $a$ & 0.00 & a \\
\hline 7 & hal & 0.25 & $\mathrm{a}$ & 0.00 & $\mathrm{a}$ & 0.00 & $\mathrm{a}$ & 0.00 & a \\
\hline 8 & gly & 0.00 & a & 0.00 & a & 0.00 & a & 0.00 & a \\
\hline 9 & sul + gly & 0.75 & a & 0.75 & a & 0.75 & $a b$ & 0.00 & a \\
\hline 10 & chl + gly & 0.00 & $\mathrm{a}$ & 0.00 & $a$ & 0.00 & $a$ & 0.00 & a \\
\hline 11 & $\mathrm{sul}+\mathrm{chl}+$ gly & 8.75 & c & 6.00 & $b$ & 2.75 & $b$ & 2.75 & b \\
\hline 12 & eth + gly & 3.50 & $a b$ & 0.50 & $\mathrm{a}$ & 0.00 & a & 0.00 & a \\
\hline \multirow[t]{2}{*}{13} & hal + gly & 5.00 & bc & 2.25 & a & 2.00 & $a b$ & 0.00 & a \\
\hline & Mean & \multicolumn{2}{|c|}{1.63} & \multicolumn{2}{|c|}{0.84} & \multicolumn{2}{|c|}{0.48} & \multicolumn{2}{|c|}{0.21} \\
\hline & CV (\%) & \multicolumn{2}{|c|}{27.76} & \multicolumn{2}{|c|}{24.66} & \multicolumn{2}{|c|}{28.56} & \multicolumn{2}{|c|}{15.94} \\
\hline & LSD & \multicolumn{2}{|c|}{4.04} & \multicolumn{2}{|c|}{2.63} & \multicolumn{2}{|c|}{2.66} & \multicolumn{2}{|c|}{1.43} \\
\hline & $\mathrm{F}$ & \multicolumn{2}{|c|}{10.745} & \multicolumn{2}{|c|}{10.052} & \multicolumn{2}{|c|}{2.858} & \multicolumn{2}{|c|}{7.118} \\
\hline & $P>F$ & \multicolumn{2}{|c|}{$0.000^{*}$} & \multicolumn{2}{|c|}{$0.000^{*}$} & \multicolumn{2}{|c|}{$0.007^{*}$} & \multicolumn{2}{|c|}{$0.000^{*}$} \\
\hline
\end{tabular}

'co (control), sul (sulfometuron - $15 \mathrm{~g}$ a.i. ha-1), chl (chlorimuron - $20 \mathrm{~g}$ a.i. ha-1) eth (ethoxysulfuron $-60 \mathrm{~g}$ a.i. ha-1), hal (halosulfuron - $80 \mathrm{~g}$ a.i. ha-1), gly (glyphosate -960 g a.e. ha-1).

Means followed by the same letter in the column do not differ from each other with the TUKEY (1949) test ( ${ }^{*}$ < 0.05$)$.

Table 4. Crop injury (\%) at 7, 14, 21 , and 28 days after application of RR2/STS soybeans under application of post-emergence herbicides. Palotina City, Paraná (experiment II), season 2017/18.

\begin{tabular}{|c|c|c|c|c|c|c|c|c|c|}
\hline \multirow{2}{*}{\multicolumn{2}{|c|}{ Treatments ${ }^{1}$}} & \multicolumn{8}{|c|}{ Crop injury } \\
\hline & & \multicolumn{2}{|c|}{7} & \multicolumn{2}{|c|}{14} & \multicolumn{2}{|c|}{21} & \multicolumn{2}{|c|}{28} \\
\hline 1 & co (without weeding) & - & & - & & - & & - & \\
\hline 2 & co (with weeding) & 0.00 & a & 0.00 & a & 0.00 & $\mathrm{a}$ & 0.00 & a \\
\hline 3 & sul & 7.00 & bc & 2.00 & $a b$ & 0.25 & $a$ & 0.00 & a \\
\hline 4 & chl & 1.00 & a & 1.75 & $a b$ & 0.25 & $\mathrm{a}$ & 0.00 & a \\
\hline 5 & $\mathrm{sul}+\mathrm{chl}$ & 9.50 & c & 7.00 & c & 3.75 & bc & 3.00 & bc \\
\hline 6 & eth & 7.50 & $b c$ & 4.75 & bc & 2.25 & $a b$ & 1.25 & $a b$ \\
\hline 7 & hal & 5.25 & $b$ & 2.00 & $a b$ & 0.50 & $\mathrm{a}$ & 0.00 & a \\
\hline 8 & gly & 0.00 & a & 0.00 & a & 0.00 & a & 0.00 & a \\
\hline 9 & sul + gly & 14.25 & d & 13.00 & d & 9.50 & $d$ & 7.00 & d \\
\hline 10 & chl + gly & 8.50 & c & 8.25 & c & 6.00 & c & 3.75 & c \\
\hline 11 & sul + chl + gly & 36.25 & g & 38.50 & $f$ & 33.50 & $f$ & 28.50 & $f$ \\
\hline 12 & eth + gly & 29.00 & $f$ & 22.25 & e & 15.50 & e & 12.00 & e \\
\hline 13 & hal + gly & 19.75 & e & 15.75 & d & 10.50 & $d$ & 6.25 & d \\
\hline & Mean & 11 & & & & & & & \\
\hline & CV (\%) & 10 & & & & & & & \\
\hline & LSD & 2. & & & & & & & \\
\hline & $\mathrm{F}$ & 365 & & 206 & & 233 & & 372 & \\
\hline & $P>F$ & 0.0 & & $0 . C$ & & $0 . C^{2}$ & & $0 . C$ & \\
\hline
\end{tabular}

${ }^{1} \mathrm{co}$ (control), sul (sulfometuron - $15 \mathrm{~g}$ a.i. ha-1 $)$, chl (chlorimuron - $20 \mathrm{~g}$ a.i. ha-1) eth (ethoxysulfuron $-60 \mathrm{~g}$ a.i. ha ${ }^{-1}$ ), hal (halosulfuron $-80 \mathrm{~g}$ a.i. ha-1), gly (glyphosate $-960 \mathrm{~g}$ a.e. $\mathrm{ha}^{-1}$ ).

Means followed by the same letter in the column do not differ from each other with the TUKEY (1949) test $\left({ }^{*} p<0.05\right)$. 
once again, all associations caused injury to soybean plants, whereas ethoxysulfuron (60 g i.a. ha-1) differed from the control only for the application of isolated herbicides. At 21 and $28 \mathrm{DAA}$, the associations caused injuries and all isolated herbicides did not differ from the control. Finally, at 28 DAA, the triple association caused $28.50 \%$ of crop injury, superior to all other treatments.

The tolerance of the BMX Garra RR2/STS cultivar for the application of the chlorimuron and glyphosate herbicides is also highlighted, which did not differ from the control for both experiments, in all evaluations of crop injury.

For the variables related to agronomic performance (experiment II), no differences were verified between treatments for height of insertion of the first pod. However, differences are verified for total plant height and yield (Table 5).

The chlorimuron, sulfometuron, halosulfuron, and glyphosate herbicides, applied in isolation, did not reduce the height of the soybean plants in relation to the control one, and all other treatments provided a reduction in height.

For the yield, some differences were verified. However, it is not possible to verify a standard for the treatments that reduce the values. The application of sulfometuron + chlorimuron + glyphosate presented lower values of soybean yield in relation to ethoxysulfuron, glyphosate and sulfometuron + glyphosate. However, it did not show reduction in relation to the control.

\section{Efficacy of herbicides in weed control}

Higher control scores were observed for the isolated application of glyphosate or in association with all sulfonylureas. For these treatments, control scores were higher than $87 \%$ in all evaluations, reaching scores above $93 \%$ at 28 DAA (Table 6). For the dry mass of weeds, the same treatments were also observed, which presented lower values and did not differ from the weeding control, which was kept free from weed infestation.

Regarding yield, the application of glyphosate - isolated or in associations - is highlighted. However, the chlorimuron and halosulfuron herbicides that presented lower values of weed control did not present reductions in yield when compared to the weeding control. Thus, only the sulfometuron and ethoxysulfuron herbicides reduced yield compared to the weeding control and were still the only ones that did not differ from the control without weeding.

\section{DISCUSSION}

As verified in the present study, RR2/STS soybeans were tolerant for post-emergence application of chlorimuron $\left(20 \mathrm{~g}\right.$ a.i. $\left.\mathrm{ha}^{-1}\right)$ and glyphosate $\left(960 \mathrm{~g}\right.$ a.e. ha- $\left.{ }^{-1}\right)$, without crop injury and reductions in variables related to agronomic performance (SILVA et al., 2016).

Table 5. Variables related to the agronomic performance of RR2/STS soybeans under application of post-emergence herbicides. Palotina City, Paraná (experiment II), season 2017/18.

\begin{tabular}{|c|c|c|c|c|c|c|}
\hline \multicolumn{2}{|c|}{ Treatments ${ }^{1}$} & \multirow{2}{*}{$\begin{array}{c}\text { HP } \\
-\end{array}$} & \multicolumn{2}{|c|}{ Height } & \multicolumn{2}{|c|}{ Yield } \\
\hline 1 & co (without weeding) & & \multicolumn{2}{|c|}{-} & \multicolumn{2}{|c|}{-} \\
\hline 2 & co (with weeding) & 26.88 & 108.97 & $a$ & 4,296 & $a b$ \\
\hline 3 & sul & 25.72 & 99.22 & abcd & 4,081 & $a b$ \\
\hline 4 & $\mathrm{chl}$ & 26.63 & 105.94 & $a b c$ & 4,079 & $a b$ \\
\hline 5 & $\mathrm{sul}+\mathrm{chl}$ & 25.82 & 95.38 & cde & 3,949 & $a b$ \\
\hline 6 & eth & 25.35 & 95.91 & bcd & 4,420 & a \\
\hline 7 & hal & 25.53 & 98.72 & abcd & 4,231 & $a b$ \\
\hline 8 & gly & 26.16 & 106.13 & $a b$ & 4,406 & $a$ \\
\hline 9 & sul + gly & 25.47 & 98.07 & bcd & 4,401 & $a$ \\
\hline 10 & chl + gly & 24.91 & 91.66 & def & 3,926 & $a b$ \\
\hline 11 & $\mathrm{sul}+\mathrm{chl}+\mathrm{gly}$ & 23.60 & 84.94 & ef & 3,809 & $b$ \\
\hline 12 & eth + gly & 24.13 & 82.57 & $f$ & 4,060 & $a b$ \\
\hline 13 & hal + gly & 25.13 & 91.75 & def & 4,274 & $a b$ \\
\hline & Mean & 25.44 & & & 41 & \\
\hline & CV (\%) & 6.67 & & & & \\
\hline & LSD & 4.22 & & & & \\
\hline & $\mathrm{F}$ & 1.228 & & & & \\
\hline & $P>F$ & $0.308^{\mathrm{ns}}$ & & & & \\
\hline
\end{tabular}

'co (control), sul (sulfometuron - $15 \mathrm{~g}$ a.i. ha ${ }^{-1}$ ), chl (chlorimuron $-20 \mathrm{~g}$ a.i. ha ${ }^{-1}$ ) eth (ethoxysulfuron $-60 \mathrm{~g}$ a.i. ha-1), hal (halosulfuron $-80 \mathrm{~g}$ a.i. ha ${ }^{-1}$ ), gly (glyphosate $-960 \mathrm{~g}$ a.e. ha-1). HP: height of first pod insertion, and height $(\mathrm{cm})$, yield $\left(\mathrm{kg} \mathrm{ha}^{-1}\right)$.

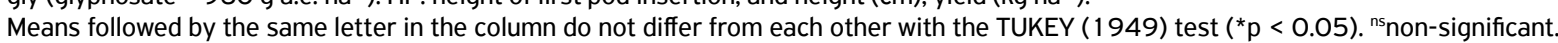


In a comparable way, the tolerance for chlorimuron (up to $60 \mathrm{~g}$ a.i. ha $\left.{ }^{-1}\right)$ was verified, and for nicosulfuron $\left(200 \mathrm{~g}\right.$ a.i. ha $\left.\mathrm{h}^{-1}\right)$ and metsulfuron (7.2 $\mathrm{g}$ a.i. $\left.\mathrm{ha}^{-1}\right)$, which are also herbicides from the sulfonylurea group (ALBRECHT et al., 2017).

Other studies also report the efficacy at weed control (POSTON et al., 2008) and selectivity (ALBRECHT et al., 2018; SILVA et al., 2018) of chlorimuron in STS soybeans. However, there is little information on its association with sulfometuron and glyphosate in RR2/STS soybeans, especially in the soil and climatic conditions of Brazil.

The halosulfuron herbicide was shown to be effective in weed control and selective for STS soybeans (NANDULA et al., 2009). The application of this herbicide, isolated or in combination, is also reported as effective in controlling weeds, such as Armoracia rusticana (JOHANNING et al., 2016), Chenopodium album, Amaranthus retroflexus, and Ambrosia artemissifolia (LI et al., 2016).

In the present study, sulfonylureas, sulfometuron, chlorimuron, halosulfuron, and ethoxysulfuron were selective for soybean plants, with greater efficacy for associations with glyphosate. However, some associations showed phytotoxic potential, mainly the sulfometuron + chlorimuron + glyphosate association.
JEFFRIES et al. (2014) observed reduction in height and biomass of SS5911N R2 (STS) cultivar for post-emergence application of sulfometuron ( $4 \mathrm{~g}$ a.i. $\left.\mathrm{ha}^{-1}\right)$. PIASECKI; RIZZARDI (2016) observed the efficacy, at control of RR maize voluntary, and selectivity of chlorimuron + sulfometuron for pre-emergence application in the BMX Turbo RR/ STS cultivar.

NONEMACHER et al. (2017) verified control of $88 \%$ of Urochloa plantaginea and Digitaria ciliaris at $21 \mathrm{DAA}$ for the application of sulfometuron $\left(15 \mathrm{~g} \mathrm{ha}^{-1}\right.$ i.a. $)+$ chlorimuron (20 a.i. ha $\left.{ }^{-1}\right)$, in pre-emergence, followed by the post-emergence application of glyphosate (1,080 a.e. ha-1).

Thus, despite the effectiveness of weed control, caution is recommended in the use of this association in STS soybeans, since the selectivity may vary with the cultivar and mode of application.

The ethoxysulfuron and halosulfuron herbicides are presented as alternatives in weed management, in association with glyphosate in RR2/STS soybeans. Despite crop injury, no reductions in soybean yield were observed for experiment II, whereas for experiment I, in addition to presenting no crop

Table 6. Weed control (\%) at 7, 14, 21, and 28 at days after application, dry mass of weeds (g) and yield (kg ha-1) of RR2/STS soybeans under post-emergence herbicide application. Piracicaba City, São Paulo (Experiment I) season 2017/2018.

\begin{tabular}{|c|c|c|c|c|c|c|c|c|c|c|c|c|c|}
\hline \multirow{2}{*}{\multicolumn{2}{|c|}{ Treatments ${ }^{1}$}} & \multicolumn{8}{|c|}{ Control } & \multirow{2}{*}{\multicolumn{2}{|c|}{$\begin{array}{c}\text { Dry } \\
\text { mass }\end{array}$}} & \multirow{2}{*}{\multicolumn{2}{|c|}{ Yield }} \\
\hline & & \multicolumn{2}{|l|}{7} & \multicolumn{2}{|c|}{14} & \multicolumn{2}{|c|}{21} & \multicolumn{2}{|c|}{28} & & & & \\
\hline \multirow{2}{*}{1} & co & \multirow{2}{*}{0.00} & \multirow{2}{*}{$d$} & \multirow{2}{*}{0.00} & \multirow{2}{*}{$d$} & \multirow{2}{*}{0.00} & \multirow{2}{*}{$d$} & \multirow{2}{*}{0.00} & \multirow{2}{*}{$\mathrm{e}$} & \multirow{2}{*}{16.78} & \multirow{2}{*}{$d$} & \multirow{2}{*}{1,945} & \multirow{2}{*}{$\mathrm{cd}$} \\
\hline & (without weeding) & & & & & & & & & & & & \\
\hline \multirow{2}{*}{2} & co & \multirow{2}{*}{100.00} & \multirow{2}{*}{ a } & \multirow{2}{*}{100.00} & \multirow{2}{*}{$a$} & \multirow{2}{*}{100.00} & \multirow{2}{*}{$\mathrm{a}$} & \multirow{2}{*}{100.00} & \multirow{2}{*}{$a$} & \multirow{2}{*}{0.00} & & 3205 & a \\
\hline & (with weeding) & & & & & & & & & & $\mathrm{a}$ & 3,395 & aD \\
\hline 3 & sul & 53.75 & c & 61.25 & bc & 56.25 & bc & 55.00 & $\mathrm{~cd}$ & 7.47 & c & 1,778 & $d$ \\
\hline 4 & $\mathrm{chl}$ & 50.00 & c & 61.25 & bc & 53.75 & bc & 46.25 & $\mathrm{~cd}$ & 12.66 & $d$ & 2,256 & bcd \\
\hline 5 & $\mathrm{sul}+\mathrm{chl}$ & 62.50 & $b$ & 67.50 & $b$ & 67.50 & $b$ & 65.00 & $\mathrm{~b}$ & 6.16 & bc & 3,597 & a \\
\hline 6 & eth & 56.25 & b & 56.25 & bc & 45.00 & c & 37.50 & $d$ & 14.59 & $d$ & 1,388 & $d$ \\
\hline 7 & hal & 47.50 & c & 47.50 & c & 45.00 & c & 40.00 & $d$ & 14.93 & $d$ & 2,195 & bcd \\
\hline 8 & gly & 88.75 & a & 93.75 & $a$ & 96.00 & $a$ & 96.50 & $a$ & 1.45 & $a b$ & 3,156 & $a b c$ \\
\hline 9 & sul + gly & 88.75 & a & 94.50 & a & 96.75 & a & 96.75 & $a$ & 0.93 & $a$ & 3,725 & $a$ \\
\hline 10 & chl + gly & 87.50 & a & 93.00 & $a$ & 94.25 & a & 94.75 & $a$ & 1.90 & $a b$ & 3,807 & $a$ \\
\hline 11 & sul + chl + gly & 89.25 & $a$ & 93.50 & $a$ & 94.25 & $a$ & 95.25 & $a$ & 1.13 & $a$ & 3,646 & $a$ \\
\hline 12 & eth + gly & 91.25 & a & 94.75 & a & 93.75 & a & 93.75 & a & 2.09 & $a b$ & 3,726 & $a$ \\
\hline 13 & hal + gly & 87.50 & a & 88.75 & $a$ & 92.50 & $a$ & 96.50 & a & 0.94 & $a$ & 3,347 & $a b$ \\
\hline & Mean & 69.4 & & 73.2 & & 71.5 & & 70.5 & & 6.2 & & 2,92 & \\
\hline & CV (\%) & 16.6 & & 17.1 & & $16 . C$ & & 12.5 & & 32. & & 17.8 & \\
\hline & LSD & 9.5 & & 9.3 & & 8.8 & & 7.1 & & 5.0 & & 1,30 & \\
\hline & $\mathrm{F}$ & 70.4 & & 69.2 & & 90.4 & & 166.1 & & 39.7 & & 11.1 & \\
\hline & $P>F$ & 0.00 & & 0.00 & & 0.00 & & 0.00 & & 0.00 & & 0.00 & \\
\hline
\end{tabular}

${ }^{1} \mathrm{co}$ (control), sul (sulfometuron - $15 \mathrm{~g}$ a.i. ha-1), chl (chlorimuron - $20 \mathrm{~g}$ a.i. ha-1) eth (ethoxysulfuron $-60 \mathrm{~g}$ a.i. ha-1), hal (halosulfuron $-80 \mathrm{~g}$ a.i. ha-1), gly (glyphosate $-960 \mathrm{~g}$ a.e. ha- ${ }^{-1}$ ).

Means followed by the same letter in the column do not differ from each other with the TUKEY $(1949)$ test $\left({ }^{*} p<0.05\right)$. 
injury, when associated with glyphosate, they were effective in weed control.

Sulfonylureas, ethoxysulfuron, and halosulfuron do not present recommendations for use in soybean. Even for STS soybeans, recommendations are not clear. Halosulfuron is registered in Brazil only for the crop of sugarcane and beans, with recommendation for control of Cyperaceae and voluntary soybean. Ethoxysulfuron is registered in Brazil for the crop of sugarcane, rice, and beans (RODRIGUES; ALMEIDA, 2018; MAPA, 2020).

Thus, the results of the present study place the two herbicides as alternatives for the control of weeds in RR2/STS soybeans. Given the possibility of using other herbicides, in addition to glyphosate, STS soybean may be an alternative for control and prevention of the selection of glyphosate resistant weeds, since the association and rotation of herbicides with different mechanisms of action are important in this sense (COUSENS; FOURNIER-LEVEL, 2018; GREEN, 2018).

\section{CONCLUSION}

Sulfometuron, chlorimuron, halosulfuron, and ethoxysulfuron herbicides, in association with glyphosate, applied in post-emergence, were effective in weed control and selective for the BMX Garra RR2/STS soybean cultivar.

The association of sulfometuron + chlorimuron + glyphosate presented phytotoxic potential for the BMX Garra RR2/STS cultivar, although without reductions in yield compared to the control without application. Therefore, caution in the recommendations of use for RR2/STS cultivars is of utmost importance.

ACKNOWLEDGEMENTS: Not applicable.

FUNDING: This work did not receive any specific grant from funding agencies in the public, commercial, or not-for-profit sectors.

CONFLICTS OF INTEREST: All authors declare that they have no conflict of interest.

ETHICAL APPROVAL: Not applicable.

AVAILABILITY OF DATA AND MATERIAL: All data generated or analyzed during this study are included in this published article.

AUTHORS' CONTRIBUTIONS: Conceptualization: Silva, A.F.M.; Albrecht, A.J.P.; Victoria Filho, R.; Albrecht, L.P.

Data curation: Silva, G.S.; Giraldeli, A.L.; Kashivaqui, E.S.F.; Ghirardello, G.A. Formal analysis: Silva, A.F.M.; Araújo, L.S.;

Albrecht, A.J.P. Writing - original draft: Silva, A.F.M. Writing - review \& editing: all authors.

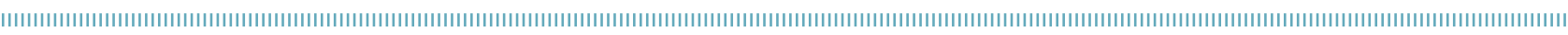

\section{REFERENCES}

ALBRECHT, A.J.P.; SILVA, A.F.M.; ALBRECHT, L.P.; PEREIRA, V.G.C.; KRENCHINSKI, F.H.; MIGLIAVACCA, R.A.; VICTORIA FILHO, R. Effect of sulfonylureas application on RR/STS soybean. Brazilian Journal of Agriculture, Piracicaba, v.92, n.1, p.37-49, 2017. https://doi.org/10.37856/bja.v92i1.3193

ALBRECHT, L.P.; ALBRECHT, A.J.P.; SILVA, A.F.M.; KRENCHINSKI, F.H.; PLACIDO, H.F.; VICTORIA FILHO, R. Rates of chlorimuron applied in glyphosate-tolerant and sulfonylurea-tolerant soybean. Journal of Crop Science and Biotechnology, Seoul, v.21, n.3, p.211-216, 2018. https://doi.org/10.1007/s12892-018-0029-0

BERNARDI, O.; MALVESTITI, G.S.; DOURADO, P.M.; OLIVEIRA, W.S.; MARTINELLI, S.; BERGER, G.U.; HEAD, G.P.; OMOTO, C. Assessment of the high-dose concept and level of control provided by MON $87701 \times$ MON 89788 soybean against Anticarsia gemmatalis and Pseudoplusia includens (Lepidoptera: Noctuidae) in Brazil. Pest Management Science, Hoboken, v.68, n.7, p.1083-1091, 2012. https://doi.org/10.1002/ps.3271
COUSENS, R.D.; FOURNIER-LEVEL, A. Herbicide resistance costs: what are we actually measuring and why? Pest Management Science, Hoboken, v.74, n.7, p.1539-1546, 2018. https://doi. org/10.1002/ps.4819

FEHR, W.R.; CAVINESS, C.E.; BURMOOD, D.T.; PENNINGTON, J.S. Stage of development descriptions for soybeans, Glycine $\max (\mathrm{L})$ Merrill. Crop Science, Madison, v.11, n.6, p.929-931, 1971. https://doi.org/10.2135/cropsci $1971.0011183 \times 00$ $1100060051 \mathrm{x}$

GREEN, J.M. Review of glyphosate and ALS-inhibiting herbicide crop resistance and resistant weed management. Weed Technology, New York, v.21, n.2, p.547-558, 2007. https://doi.org/10.1614/ WT-06-004. 1

GREEN, J.M. The benefits of herbicide-resistant crops. Pest Managemant Science, Hoboken, v.68, n. 10, p.1323-1331, 2012. https://doi.org/10.1002/ps.3374 
GREEN, J.M. The rise and future of glyphosate and glyphosate-resistant crops. Pest Management Science, Hoboken, v.74, n.5, Special Issue: Glyphosate, p.1035-1039, 2018.https://doi.org/10.1002/ps.4462

JEFFRIES, M.D.; MAHONEY, D.J.; GANNON, T.W. Effect of simulated indaziflam drift rates on various plant species. Weed Technology, New York, v.28, n.4, p.608-616, 2014. https://doi.org/10.1614/ WT-D-14-00004. 1

JOHANNING, N.R.; WALTERS, S.A.; YOUNG, B.G. Herbicides for control of volunteer horseradish (Armoracia rusticana) and potential carryover to subsequent horseradish production. Weed Technology, New York, v.30, n. 1, p. 181-189, 2016. https://doi. org/10.1614/WT-D-15-00087.1

LI, Z.; ACKER, R.V.; ROBINSON, D.E.; SOLTANI, N.; SIKKEMA, P.H. Halosulfuron tankmixes applied preplant incorporated for weed control in white bean (Phaseolus vulgaris L.). Canadian Journal of Plant Science, Ottawa, v.96, n.1, p.81-88, 2016. https://doi. org/10.1139/cjps-2015-0124

MANTOVANI, E.E.; SOUZA, N.O.S.; SILVA, L.A.S.; SANTOS, M.A. Characterization of soybean population with sulfonylurea herbicides tolerant alleles. African Journal of Agricultural Research, Lagos, v.12, n.19, p.1661-1668, 2017. https://doi.org/10.5897/ AJAR2017.12251

MINISTÉRIO DA AGRICULTURA, PECUÁRIA E ABASTECIMENTO (MAPA). Sistema de agrotóxicos fitossanitários - AGROFIT. 2020. Available from: http://agrofit.agricultura.gov.br/agrofit_cons/ principal_agrofit_cons. Access on: Aug. 102020.

NANDULA, V.K.; POSTON, D.H.; REDDY, K.N.; WHITING, K. Response of soybean to halosulfuron herbicide. International Journal of Agronomy, New York, v.2009, p.1-7,2009. http://dx.doi.org/10.1155/2009/754510

NONEMACHER, F.; GALON, L.; SANTIN, C.O.; FORTE, C.T.; FIABANE, R.C.; WINTER, F.L.; AGAZZI, L.R.; BASSO, F.J.M.; PERIN, R.R.K. Associação de herbicidas aplicados para o controle de plantas daninhas em soja resistente ao glyphosate. Revista Brasileira de Herbicidas, Londrina, v.16,n.2,p.142-151,2017.https://doi.org/10.7824/rbh.v16i2.529

OLIVEIRA JÚNIOR, R.S. Mecanismos de ação dos herbicidas. In: OLIVEIRA JÚNIOR, R.S.; CONSTANTIN, J.; INOUE, M.H. (Eds.). Biologia e manejo de plantas daninhas. Curitiba: Ominipax, 2011.p.141-192.

PADGETTE, S.R.; KOLACZ, K.H.; DELANNAY, X.; RE, D.B.; LAVALLEE, B.J.; TINIUS, C.N.; RHODES, W.K.; OTERO, Y.I.; BARRY, G.F.; EICHHOLTZ, D.A.; PESCHKE, V.M.; NIDA, D.L;;AYLOR, N.B.; KISHORE, G.M. Development, identification, and characterization of a glyphosate-tolerant soybean line. Crop Science, Madison, v.35, n.5, p.1451-1461, 1995. https:// doi.org/10.2135/cropsci1995.0011183X003500050032x

PIASECKI, C.; RIZZARDI, M.A. Herbicidas aplicados em pré-emergência controlam plantas individuais e touceiras de milho voluntário $R^{\circledR} F 2$ em soja? Revista Brasileira de Herbicidas, Londrina, v.15, n.4, p.323331, 2016. https://doi.org/10.7824/rbh.v15i4.497
PIMENTEL-GOMES, F.; GARCIA, C.H. Estatística aplicada a experimentos agronômicos e florestais: exposição com exemplos e orientações para uso de aplicativos. Piracicaba: FEALQ, 2002. 309p.

POSTON, D.H.; NANDULA, V.K.; KOGER, C.H.; MATT GRIFFIN, R. Preemergence herbicides effect on growth and yield of earlyplanted Mississippi soybean. Crop Management, Madison, v.7, n. 1, p. 1-14, 2008. https://doi.org/10.1094/CM-2008-0218-02-RS

RODRIGUES, B.N.; ALMEIDA, F.S. Guia de herbicidas. 7.ed. Londrina: Editing authors, 2018.

ROGOZIN, I.B.; BERIKOV, V.B.; VASUNINA, E.A.; SINITSINA, O.I. The effect of the primary structure of DNA on induction of mutations by alkylating agents. Russian Journal of Genetics, Moscow, v.37, n.6, p.704-710, 2001. https://doi. org/10.1023/A:1016641812010

ROSO, A.C.; VIDAL, R.A. Culturas resistentes aos herbicidas inibidores da enzima ALS: revisão de literatura. Pesticidas: Revista de Ecotoxicologia e Meio Ambiente, Curitiba, v.21, p.13-24, 2011. http://dx.doi.org/10.5380/pes.v2 1 i0.25849

SEBASTIAN, S.A.; FADER, G.M.; ULRICH, J.F.; FORNEY, D.R.; CHALEFF, R.S. Semidominant soybean mutation for resistance to sulfonylurea herbicides. Crop Science, Madison, v.29, n.6. p.1403-1408, 1989. https://doi.org/10.2135/cropsci 1989 $.0011183 \times 002900060014 x$

SILVA, A.F.M.; ALBRECHT, A.J.P.; ALBRECHT, L.P.; VICTORIA FILHO, R.; GIOVANELLI, B.F. Application of post-emergence als inhibitor herbicides associated or not to glyphosate in RR/STS soybean. Planta Daninha, Viçosa, v.34, n.4, p.765-775, 2016. http://dx.doi.org/10.1590/s0100-83582016340400017

SILVA, A.F.M.; ALBRECHT, A.J.P.; DAMIÃO, V.W.; GIRALDELI, A.L.; MARCO, L.R.; PLACIDO, H.F.; ALBRECHT, L.P.; VICTORIA FILHO, R. Selectivity of nicosulfuron isolated or in tank mixture to glyphosate and sulfonylurea tolerant soybean. Journal of Plant Protection Research, Poznań, v.58, n.2, p. 152-160, 2018. https://doi.org/10.24425/122930

TUKEY, J.W. Comparing individual means in the analysis of variance. Biometrics, Hoboken, v.5, n.2, p.99-1 14, 1949. https:// doi.org/10.2307/3001913

VELINI, D.E.; OSIPE, R.; GAZZIERO, D.L.P. (Coord.). Procedimentos para instalação, avaliação e análise de experimentos com herbicidas. Londrina: SBCPD, 1995. 42p.

WALTER, K.L.; STRACHAN, S.D.; FERRY, N.M.; ALBERT, H.H.; CASTLE, L.A.; SEBASTIAN, S.A. Molecular and phenotypic characterization of $A / s 1$ and $A / s 2$ mutations conferring tolerance to acetolactate synthase herbicides in soybean. Pest Managemant Science, Hoboken, v.70, n.12, p.1831-1839, 2014. https://doi. org/10.1002/ps.3725 